\title{
Antecedents of Performance Appraisal and Organizational Performance in Water and Sanitation Companies in Kenya: A Case of Murang'a Water and Sanitation Company limited
}

\author{
Elijah Ng'ang'a Njuguna ${ }^{1}$, Bula Hannah Orwa ${ }^{2, *}$ \\ ${ }^{1}$ School of Business, Kenyatta University, Nairobi, Kenya \\ ${ }^{2}$ Department of Business Administration, School of Business, Kenyatta University, Nairobi, Kenya
}

Email address:

bula.oh@yahoo.com (B. H. Orwa)

\section{To cite this article:}

Elijah Ng'ang'a Njuguna, Bula Hannah Orwa. Antecedents of Performance Appraisal and Organizational Performance in Water and Sanitation Companies in Kenya: A Case of Murang'a Water and Sanitation Company limited. International Journal of Business and Economics Research. Vol. 4, No. 5, 2015, pp. 250-263. doi: 10.11648/j.ijber.20150405.14

\begin{abstract}
Performance appraisal serves a good number of purposes in organizations. In the context of socialization, performance appraisal provides important feedback about how well the individual is getting along in the organization. This general objective of this study was to assess the impact of performance appraisal on organizational performance in Murang'a water and Sanitation Company. The study also sought to establish the effects of goal setting in performance appraisal, feedback in performance appraisal and performance appraisal on the organizational performance on Murang'a water and Sanitation Company. This study employed a descriptive research survey. The census for this study was 94 employees working in Murang'a water and Sanitation Company. In addition the study used primary data collected using questionnaires; the questionnaires included structured and unstructured questions. Data collected was mainly quantitative in nature and was appropriately analyzed using descriptive statistics. The descriptive statistical tools helped in describing the data and determine the extent to be used. These included frequencies, percentages, mean and standard deviations. In addition, multiple regression analysis was used to establish the relationship between dependent and the independent variable. SPSS (Statistical Package for Social Sciences), was used in analysis. The study established that employees' knowledge and skills in performance appraisal influences the organizational performance in Murang'a water and Sanitation Company most followed by feedback in performance appraisal and goal setting in performance appraisal. The study therefore recommends that Murang'a water and Sanitation Company should set its goals with employees in mind. In addition, the organization should ensure that all employees understand the organization's goals.
\end{abstract}

Keywords: Performance Appraisal, Organization Performance, Water Sanitation Knowledge, Feedback, Goal Setting

\section{Background of the Study}

Performance testing is an informational system which is the essential core of the performance appraisal process (Tuytens \& Devos, 2012). This has a vital significance for the system of performance appraisal to be effective and efficient. Firms engage in the performance-appraisal process for numerous reasons. Managers may conduct performance appraisal to affect employee behavior through the feedback process, or to justify some sort of human resource management action. However, many other benefits may also accrue from the information yielded by the appraisal. These benefits include increases in knowledge regarding the effectiveness of selection and placement programs, training and development needs, budgeting; human resource planning, and reward decisions (Cardy \& Dobbins, 2008). In general, Kuvaas (2006) has defined developmental performance appraisal as each attempt that results in enrichment of viewpoints, experiences and skills in order to improve employees' efficiency. Performance appraisal is an action for testing, measuring, valuating and justifying about the performance during a certain period of time. It is synonymous with improvement of individuals' effectiveness and process of the organization's business from organizational viewpoint (Roberts \& Reed, 2008).

Performance appraisal help an organization in realizing its strategic purposes and in increasing of effective working processes through continuous improvement of individuals' 
performance and processes along with focusing on weak improvable points (Cameron \& Pierce, 2004). With due attention to the fact that Performance appraisal is one of the main parts of organizational life and could consist of several organizational processes such as measuring of work performance, establishing of purposes and reward management (Cardy \& Dobbins, 2008), however many organizations express dissatisfaction about the designs of their performance appraisal procedures (Salleh et al., 2013).

Generally, the agreement among researchers in the field of performance appraisal is that assessing reflections and reactions of appraisal is very important (Selvarajan \& Cloninger, 2012).. Employees should experience positive reflections of performance appraisal to reinforce the good traits (Cardy \& Dobbins, 2008). Kuvaas, (2006) agrees that performance appraisal is a key concept human resources management and is one of the subjects which have been studied and investigated in the psychology of work extremely systems of performance appraisal for example were not comprehensively studied until the year 2000 when a study was done in a spinning factory in Scotland and brought forth a realistic platform for modern day performance appraisal studies. (Caruth \& Humphreys, 2008). Pettijohn et al., (2001) considers systems of performance appraisal as one of the most vital subjects of human resources in 21 century (Heresy and Blanchard, 2009). Today Performance appraisal has been transformed to a strategic approach for integrating of human resources activities and business policies. Given that organizations try to evaluate employees and growth and improvement of their capabilities, increasing of performance and distribution of reward, Performance appraisal is observed as a subject that covers various activities (Fletcher, 2001).

One of the ways that organizations can apply developmental performance appraisal is using of performance appraisal activities in relation with determining of strategies, purposes and organizational .Performance appraisal is argued to cause the increase employees' understanding of the sense of being valuable and know themselves as a part of the organizational team that is the main understanding for being committed to the organization. If reflections that have been obtained from Performance appraisal satisfaction are being invested in developing of employees, then probably employees will compensate it through increasing of effective commitment in the organization (Locke \& Latham, 2007).

Studies about organizational justice reveal that distributive justice and procedural justice have unique and mutual relations with organizational commitment (McGregor, 2008). Those individuals who feel injustice from results of performance appraisal will more probably quit the organization or they will show lower levels of organizational commitment from themselves. And even they may embark on abnormal behaviors like taking vengeance from the organization (Deci, Connell \& Ryan, 2008).

\subsection{Murang'a Water and Sanitation Company}

The Murang'a Water and Sanitation Company Limited
(MUWASCO) was incorporated on $14^{\text {th }}$ March 2006 under the Companies Act CAP 486 of the Laws of Kenya. It was incorporated as a company limited as a guarantee to give it autonomy to operate commercially. The company is contracted by Tana Water Services Board, a state corporation established under the Water Act of 2002. It is mandated to provide efficient and economical water and sanitation services within Murang'a Municipality and its immediate environs through signing of a Service Provision Agreement (SPA) between MUWASCO and Tana Water Services Board (TWSB). The key principle of forming the company was to merge water provision, previously under the District Water Office and Sewerage services from the Municipal council of Murang'a. Also to RING FENCE the water and sewerage income for reinvestment in the water and sewerage services and enhance service delivery efficiency. The Company consists of nine Board members who are appointed by the stake holders and covers an area of approximately twelve kilometers squared $(12 \mathrm{Km} 2)$. It has its headquarters off Kangema Road-Murang'a town and has so far 6,839 active water connections and 7,840 registered connections. The Company's management is headed by a Managing Director and has three main departments namely: Technical Services, Commercial Department and Human Resources \& Administration Department

\subsection{Statement of the Problem}

Some organizations experience dissatisfaction with their performance appraisal procedure signaling that performance appraisal is not fully successful as a mechanism for developing and motivating employees (Sorensen, Severinson \& Iedama, 2008). Performance appraisal can be considered to be a technique that has a positive effect on work environment and quality of service. There are a number of problems connected to performance appraisal which include poor design, lack of attention to the organizational culture, and unwillingness to confront issues of poor performance, as well as time pressure.

Performance appraisal provides a good opportunity to formally recognize employees' achievements and contributions to the organization, and to ensure that a clear link is established and maintained between performance and reward. However, poor infrastructure, inadequate logistics and equipment, poor remuneration and inadequate reward system have always led to the low level of performance in organizations.(Gbadamosi \& Ross (2012). There is no empirical evidence on the impact of performance appraisal on organizational performance in Murang'a County. This study sought to fill this research gap by assessing the impact of performance appraisal on organizational performance by focusing on Murang'a water and Sanitation Company.

\subsection{Specific Objectives of the Study}

i. To determine the effect of goal setting in performance appraisal on organizational performance in Murang'a water and Sanitation Company. 
ii. To establish the effect of employees' knowledge and skills in performance appraisal on the organizational performance in Murang'a water and Sanitation Company

iii. To assess the effects of feedback in performance appraisal on the organizational performance in Murang'a water and Sanitation Company.

\subsection{Research Questions}

The study sought to answer the following research questions

i. What is the effect of goal setting in performance appraisal on organizational performance in Murang'a water and Sanitation Company?

ii. What are the effects of employees' knowledge and skills in performance appraisal on the organizational performance in Murang'a water and Sanitation Company?

iii. What are the effects of feedback in performance appraisal on the organizational performance in Murang'a water and Sanitation Company?

\section{Literature Review}

\subsection{Goal Setting Theory}

The study made use goal setting theory to scrutinize performance against the company's goals. Since it was first researched five decades ago, goal-setting theory has been the most researched, utilized, and established theory of work motivation in the field of industrial and organizational psychology. The theory began with the early work on levels of aspiration developed by Kurt and Locke(1968). The research revealed an inductive relationship between goal setting and improved production performance. A goal is the aim of an action or task that a person consciously desires to achieve or obtain (Locke \& Latham, 2006). Goal setting involves the conscious process of establishing levels of performance in order to obtain desirable outcomes. If individuals or teams find that their current performance is not achieving desired goals, they typically become motivated to increase effort or change their strategy.

The relationship between goal difficulty, level of performance, and effort involved is critical in performance appraisal. This relationship will stay positive, as long as the person under scrutiny is committed to the goal, has the requisite ability to attain it, and doesn't have conflicting goals Locke and Latham's goal setting theory states that several conditions are particularly important in successful goal achievement. These include goal acceptance and commitment, goal specificity, goal difficulty, and feedback. These conditions have been extended and edited by other researchers, such as Kenneth Blanchard and Spencer Johnson's SMART goals, which are conditions that are necessary to make goals effective (Thurston \& McNall, 2010).

According to Walsh \& Fisher (2005), the two most important findings of this theory are that setting specific goals generates higher levels of performance than setting general goals, and that goals that are hard to achieve are linearly and positively connected to performance. The harder the goal, the more a person will work to reach it. However, such influences on performance are mediated by feedback, and that the person in question accepts the goal.

\subsection{Equity Theory}

Adams (1963) says that satisfaction is based on a person's perception of fairness. The study applied this theory to analyze the company's performance appraisals involving balancing the assessment of an employee's contribution to his job with the compensation and other rewards associated with his success as supported by (Caruth \& Humphreys, 2008). In general, highly-paid and rewarded employees tend to be the most motivated to continue performing well on the job.People typically value fair treatment which is directly connected to job performance. According to equity theory, an employee's perception of the fairness of his work's input and outcome influences his motivation (Salleh et al., 2013). Effective performance management systems enable a manager to clarify job responsibilities and expectations, develop an employee's capabilities, and align an employee's behavior to the company's strategic goals and values. An employee typically feels satisfied with the outcome of his effort, including his pay, when the compensation matches what he feels he puts into the job. If an employee perceives that others get more for doing less, he typically becomes less motivated to work hard. Managers create a productive work environment by communicating job requirements clearly and establishing fair and consistent performance objectives for all employees.

It is not easy to make equitable decisions while supporting performance improvement. Managers typically evaluate their employees, calibrate ratings and decide on rewards. These rewards include pay increases, promotions, flexible work schedules or stock options. Justifying these decisions becomes the focus, rather than relaying constructive feedback that can enhance performance and foster career development (Gbadamosi \& Ross, 2012).

\subsection{Feedback in Performance Appraisal on the Organizational Performance}

Performance appraisal process is incomplete without the feedback given to the employee about his appraisal and his performance. But the way of giving as well as receiving the feedback differs from person to person and their way of handling and their outlook towards the issue (Heslin, Latham \& VandeWalle, 2005).

Performance appraisal helps employees to improve their performance by giving specific feedback about the need for development, and helps employees to continue to excel by giving positive reinforcement that can motivate them (Kuvaas, 2006). This type of feedback may be essential to improve performance of employees at all levels. Feedback is 
perhaps the most important component of performance appraisal. Feedback is often seen as recognition for good performance, and can increase inner motivation because it may reinforce the employees' own competence and selfesteem.

Feedback may have a negative impact on staff motivation when the conversation consists of invidious words and phrases or rambling conversations. Several researchers suggest that there are many other negative consequences associated with giving feedback, such as time pressure, disturbances, unfortunate procedures and social anxiety (Theresa \& Sulsky, 2008). Feedback from managers is related to increased performance and job motivation. Researchers also show that employees with higher education do not receive more feedback than those with less education, but they are given more positive feedback (Kipyegon, 2012).

Furthermore, researchers point out that less educated workers are not motivated by feedback in the performance appraisal at all. They suggest that the source of the feedback may influence the recipient's perception and acceptance. Both empirical studies and theories suggest that people are reluctant to give negative feedback and may distort it in a more positive direction when they are required to offer feedback (Dunning, Durham \& McDonough, 2012). If effective feedback is given to employees on their progress towards their goals, employee performance will improve. People need to know in a timely manner how they are doing, what is working, and what is not. (Tuytens \& Devos, 2012)

Feedback should be given in a manner that will best help improve performance. Since people respond better to information presented in a positive way, feedback should be expressed in a positive manner (Gbadamosi \& Ross, 2012). This is not to say that information should be sugar-coated. It must be accurate, factual, and complete. When presented, however, feedback is more effective when it reinforces what the employee did right and then identifies what needs to be done in the future

Some kinds of feedback occur naturally while other kinds must be carefully planned and well-managed. Naturallyoccurring feedback can be classified into two categories. The first type is self-evident feedback-information that employees can see for themselves as they do their work The second category of feedback is carefully planned feedback that is designed to be given often and automatically through a measurement system. Feedback can be designed into a work process or a measurement system so that it is received automatically by the employee. For example, many work processes have been designed to provide performance measures daily, such as a production or printing process, i.e. so many copies printed per day as determined by machine count. Also, total quality and reengineering programs use extensive work process measurement methods. Employees can measure for themselves how they and their team are doing (Gupta \& Kumar, 2013).

\subsection{Employees' Knowledge and Skills in Performance Appraisal}

The most powerful phrases in this area focus not only on employees' knowledge, expertise, and technical skills, but also on the ways in which employees apply these factors to their work. In light of the key role played by job knowledge what is important is to make sure that one uses knowledgeable phrases when providing feedback in this area (Lloyd 2009).

On the other hand, intrinsic motivation is associated with professional knowledge and skills. Personnel with sufficient skills, knowledge and high intrinsic motivation may actually have less need for external regulation than those with less education and less intrinsic motivation (Gbadamosi \& Ross, 2012). Intrinsically motivated employees may benefit more from performance appraisal because they will learn more from the appraisal they are given. There is a negative relationship between performance appraisal satisfaction and work performance for employees with low intrinsic motivation (Cameron \& Pierce, 2004). Motivated employees react positively to performance appraisal due to their professional knowledge, individual ability, skills and good task orientation. Extrinsic motivation appears to be best suited to relatively trivial, simple, standardized tasks or jobs, which in principle are not intrinsically motivating. The most important thing is to get the job done with a satisfactory outcome, and where sustained positive long-term effects on behavior and attitudes are not expected. Motivation, knowledge and independence are useful components of a worker's day, that may minimize employees work environment problems. Several models have emerged that have tended to guide the research in this area. Researchers have four components in one of their performance appraisal models: context (culture, conflicts, knowledge, etc.), judgment (sensitive questions), rating and appraisal (motivation) (Gbadamosi \& Ross, 2012).

\subsection{Goal Setting in Performance Appraisal on the Organizational Performance}

Goal setting is effective as long as employees accept it, and it is a visible process and a key component of performance appraisal participation. Goal setting theory has been dominated by job motivation theory in the last decade. The theory focuses on mobilization, tasks, continual encouragement, feedback in the job and strategy for the employees own development. Goals may be divided into four categories: performance goals, interpersonal goals, strategic goals and internalization goals (Caruth \& Humphreys, 2008). In performance appraisal, the participant may be connected to several of these goal categories. The basic approach in performance appraisal is that the manager and their subordinates focus on the same goals. Differences in education, employment, training, but also time pressures, shift work and the use of temporary workers may make this coordination difficult (Tuytens \& Devos, 2012). 
When discussing the use of performance appraisal, it is important to distinguish among the various goals that participants have for the process, because these goals may be different (Gbadamosi \& Ross, 2012). A performance appraisal will probably work best when formal goals, organizational goals, and the ratees' and rater's goals for performance appraisal are compatible. Several researchers have also made a distinction between the concepts of "goals" and "standards", where goals are described as being internally imposed, while standards are externally imposed, for instance by managers. Participation in the process of setting standards and goals probably increases the chances of commitment (Cardy \& Dobbins, 2008). Performance appraisal takes place where goals are set within SMART objectives motivation is always at its best. Rotich R.K (2012).

\subsection{Conceptual Framework}

This study sought to assess the impact of performance appraisal on organizational performance in Murang'a water and Sanitation Company. The independent variables in this study were feedback in performance appraisal, employees' knowledge and skills in performance appraisal and goal setting in performance appraisal. This study therefore sought to establish how the independent variables influence the dependent variable (organizational performance).

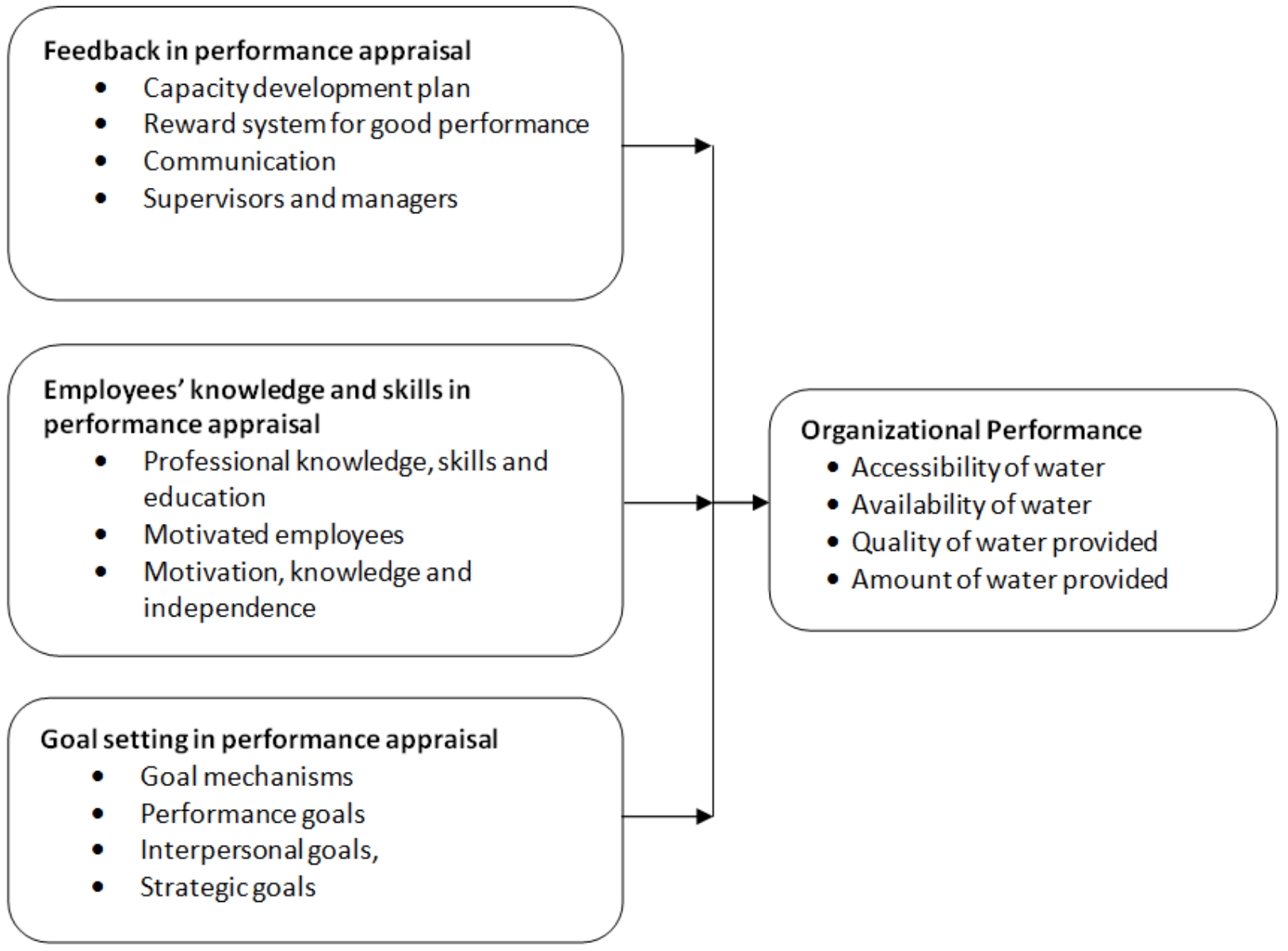

Independent Variables

Dependent Variable

Source: Researcher, 2013

Figure 1. Conceptual Framework.

\section{Research Methodology}

\subsection{Research Design}

This study used a descriptive research design. This design refers to a set of methods and procedures that describe variables. It involves gathering data that describe events and then organizes, tabulates, depicts, and describes the data. Descriptive studies portray the variables by answering who, what, and how questions (Babbie, 2002). Its advantage is that, it is used extensively to describe behavior, attitude, characteristic and values. According to Kothari (2004), descriptive design is the precise measurement and reporting of the characteristics of the phenomena under investigation, and describes phenomena, situations and events. In this regard, this study investigated performance appraisal at Murang'a Water and Sanitation Company limited (MUWASCO). 


\subsection{Target Population}

The target was all water and sanitation companies in Muranga county whose size was 94 employees spread in the following departments: Commercial, Customer Care, Administration, Human Resource, Information Technology, Treatment Works, Workshop, Distribution, Operation and Maintenance, Metering, and Non-Revenue Water.

\subsection{Data Collection}

Questionnaires were distributed through drop and pick later method with an enclosed self- addressed return envelope to help increase response rate. This was followed by the personal visit and telephone calls.

\subsection{Instruments Validity}

Validity is defined as the degree to which results obtained from an analysis of data actually represents the phenomena under study (Mugenda \& Mugenda, 1999). Validity of a data collection tool ensures that the items in the instrument are representative of the subject area while the content validity ensures that the tool actually measures what it is supposed to measure (Fraenkel \& Wallen, 2000). Validity was ensured by having objective questions included in the questionnaire. The questionnaire was pre-tested by asking five colleagues whether the questions are clearly worded and easily understood (whether they know the answers or not). In addition, the validity of the research instruments was established by seeking opinions of experts in the field of study especially the supervisors.

\subsection{Instruments Reliability}

A reliable instrument consistently yields the same results when used repeatedly to collect data from the same sample drawn from a population (Orodho, 2005). Reliability is therefore the degree to which research instruments yields consistent results when administered a number of times (Shaw\& wright,1969). An instrument is reliable when it measures a variable accurately and consistently is used repeatedly under similar conditions. Reliability of a questionnaire is concerned with the consistency of responses to the researcher's questions (Mitchell ,1996).

Reliability on the other hand was ensured by pre-testing the questionnaire with a selected sample that will not be included in the main study. An internal consistency technique was applied by use of Cronbach's Alpha. The alpha value ranges between 0 and 1 with reliability increasing with the increase in value. Coefficient of 0.7 and above is a commonly accepted rule of thumb that indicates acceptable reliability (Kothari, 2004). The pilot data was not be included in the actual study.

In the pilot test three constructs were studied which include goal setting, employees' knowledge and skills and feedback in performance appraisal. The findings of the pilot test showed that 'goal setting' scale had a Cronbach's reliability alpha of 0.723 , 'employees' knowledge and skills' scale had an Alpha value of 0.767 and 'feedback in performance appraisal' had an Alpha value of 0.797 . This implies that the scales measuring the objectives met the reliability criteria $(\alpha>0.6)$. This therefore indicated that the research tool was sufficiently reliable and valid and needed no amendment.

Table 1. Cronbach's Reliability Alpha.

\begin{tabular}{ll}
\hline Construct & Cronbach's reliability alpha \\
\hline Goal setting & 0.723 \\
Employees' knowledge and skills & 0.767 \\
Feedback in performance appraisal & 0.797 \\
\hline
\end{tabular}

Source: Surveyor, 2013.

\subsection{Sampling Procedure and Sample size}

The researcher used stratified random sampling to select $30 \%$ of the respondents from each of the departments in MUWASCO. According to Mugenda and Mugenda (2003) a $10-30 \%$ sample of the target population is a good representation.

\subsection{Data Analysis and Presentation}

This study collected qualitative data. Descriptive statistics and inferential statistics were used to analyze quantitative data with the help of Statistical Package for Social Sciences (SPSS). Descriptive statistics included percentages, frequency distribution and measures of central tendencies (mean). The data was presented in tables and graphs. Descriptive statistics enable the researcher to meaningfully describe a distribution of measurements and also to describe, organize and summarize data (Mugenda \& Mugenda, 2003).

The study used multivariate regression analysis to establish the relationship between the independent variable and dependent variables. The regression model in this study was;

$$
\mathrm{Y}=\beta 0+\beta 1 \mathrm{X} 1+\beta 2 \mathrm{X} 2+\beta 3 \mathrm{X} 3+\varepsilon
$$

Whereby $\mathrm{Y}=$ Organizational Performance

$\mathrm{X} 1=$ Goals setting

$\mathrm{X} 2=$ Employees knowledge and skills

$\mathrm{X} 3=$ Feedback on appraisal

$\varepsilon=$ Error Term

$\beta 0, \beta 1, \beta 2, \beta 3=$ Unknown parameters

\subsection{Response Rate}

Out of 94 respondents, 92 correctly filled and returned their questionnaires. This represents a $97.87 \%$ response rate. This conforms to Mugenda and Mugenda (2003) argument that a response rate of $50 \%$ is adequate for analysis and reporting and a response rate of $70 \%$ and over is excellent. This clearly shows that the response rate in this study was excellent. 


\section{Organizational Performance}

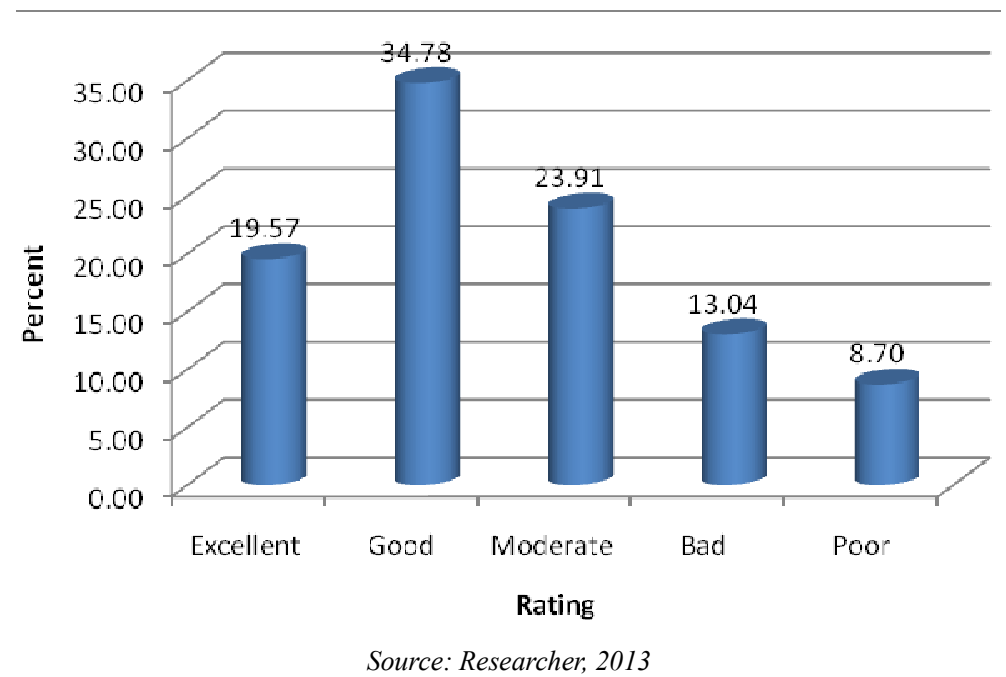

Figure 2. Performance of MUWASCO.

According to the findings, $34.78 \%$ of the respondents indicated that the performance of their organization was good, $23.91 \%$ indicated that it the performance of their organization was moderate, $19.57 \%$ of the respondents indicated that the performance of their organization was excellent, $13.04 \%$ indicated that it was bad and $8.7 \%$ indicated that it was poor. From these findings we can infer that the performance of Murang'a Water and Sanitation Company Limited was good.

Table 2. Factors Affecting the Performance of MUWASCO.

\begin{tabular}{lll}
\hline & Mean & Std Deviation \\
\hline Feedback in employee appraisal & 4.012 & 0.781 \\
Employees' knowledge and skills & 3.781 & 0.872 \\
Goal setting in performance appraisal & 3.872 & 0.786 \\
\hline
\end{tabular}

Source: Researcher, 2013
From the findings, the respondents indicated with a mean of 4.012 and a standard deviation of 0.781 that feedback in employee appraisal was affecting the performance of Murang'a Water and Sanitation Company Limited to a great extent. In addition, the respondents indicated with a mean of 3.872 and a standard deviation of 0.786 that goal setting in performance appraisal was affecting the performance of Murang'a Water and Sanitation Company Limited to a great extent. Further, the respondents indicated with a mean of 3.781 and a standard deviation of 0.872 that employees' knowledge and skills was affecting the performance of Murang'a Water and Sanitation Company Limited to a great extent.

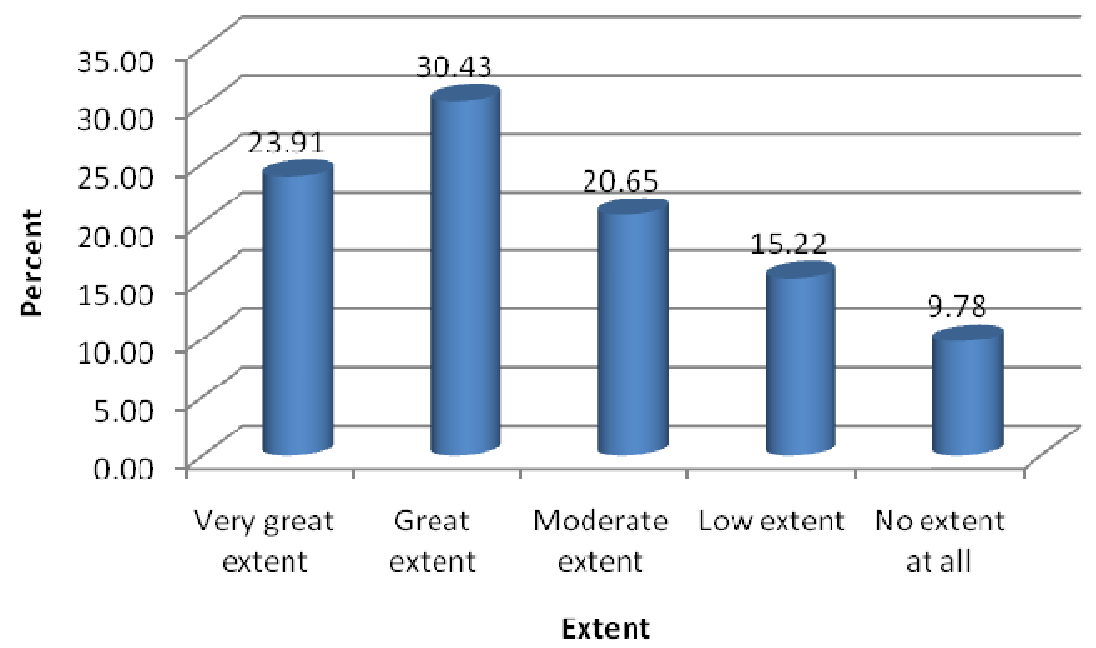

Source: Researcher, 2013

Figure 3. Influence of Goal setting on Organizational Performance. 


\subsection{Influence of Goal Setting on Organisational Performance}

The respondents were further asked to indicate the extent to which goal setting in performance appraisal was influencing organizational performance of Murang'a Water and Sanitation Company Limited.

From the findings, $30.43 \%$ of the respondents indicated that goal setting in performance appraisal was influencing organizational performance of Murang'a Water and Sanitation Company Limited to a great extent, $23.91 \%$ indicated to a very great extent, $20.65 \%$ indicated to a moderate extent, $15.22 \%$ indicated to a low extent and $9.78 \%$ indicated to no extent at all. From these findings we can deduce that goal setting in performance appraisal was influencing organizational performance of Murang'a Water and Sanitation Company Limited to a great extent.

From the findings, the respondents agreed with a mean of 4.092 and a standard deviation of 0.746 that in performance appraisal, the participant may be connected to performance goals, interpersonal goals, strategic goals and internalization goals. The respondents also agreed with a mean of 4.028 and a standard deviation of 0.635 that goals also lead to a persistent pursuit of reaching the goal by providing a purpose for that pursuit. Additionally, the respondents agreed with a mean of 3.874 and a standard deviation of 0.889 that goal setting is effective as long as employees accept it, and it is a visible process and a key component of PA participation. Further, the respondents agreed with a mean of 3.782and a standard deviation of 0.562 that performance appraisal probably work best when formal goals, organizational goals, and the ratees' and rater's goals for PA are compatible. The respondents also indicated with a mean of 3.453 and a standard deviation of 0.762 that goal mechanisms affect performance by increasing motivation to reach set goals. Lastly, the respondents indicated with a mean of 3.255 and a standard deviation of 0.526 that goals energize people to expend more effort based upon the effort that is required to reach a certain goal.

Table 3. Feedback in performance appraisal and organizational performance.

\begin{tabular}{lll}
\hline & Mean & Std Deviation \\
\hline $\begin{array}{l}\text { In PA, the participant may be connected to } \\
\text { performance goals, interpersonal goals, } \\
\text { strategic goals and internalization goals }\end{array}$ & 4.092 & 0.746 \\
$\begin{array}{l}\text { Goals also lead to a persistent pursuit of } \\
\text { reaching the goal by providing a purpose for } \\
\text { that pursuit }\end{array}$ & 4.028 & 0.635 \\
$\begin{array}{l}\text { Goal setting is effective as long as employees } \\
\text { accept it, and it is a visible process and a key }\end{array}$ & 3.874 & 0.889 \\
$\begin{array}{l}\text { component of PA participation } \\
\text { PA probably work best when formal goals, } \\
\text { organizational goals, and the ratees' and rater's } \\
\text { goals for PA are compatible }\end{array}$ & 3.782 & 0.562 \\
$\begin{array}{l}\text { Goal mechanisms affect performance by } \\
\text { increasing motivation to reach set goals }\end{array}$ & 3.453 & 0.762 \\
$\begin{array}{l}\text { Goals energize people to expend more effort } \\
\text { based upon the effort that is required to reach a } \\
\text { certain goal }\end{array}$ & 3.255 & 0.526 \\
\hline
\end{tabular}

Source: Researcher, 2013

\subsection{Influence of Feedback on Organizational Performance}

The respondents were requested to indicate whether feedback in performance appraisal influence performance in their organization.

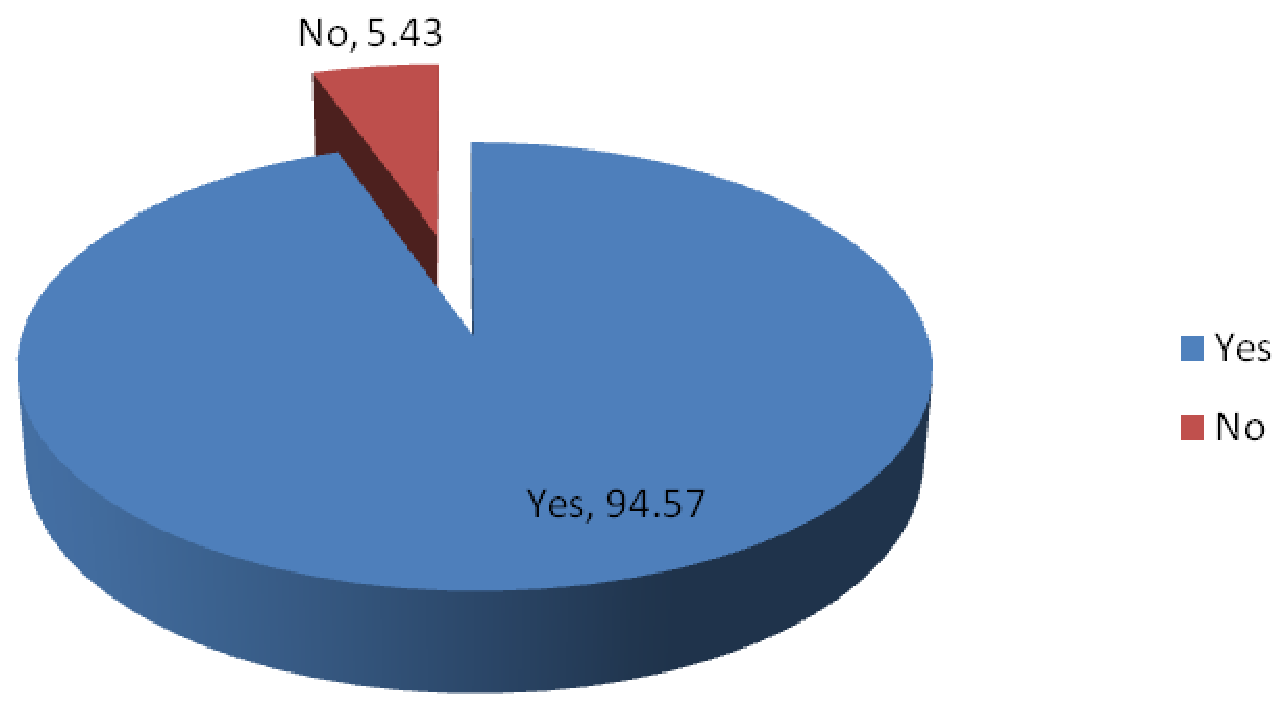

Source: Researcher, 2013

Figure 4. Influence of Feedback on Organizational Performance.

According to the findings, $94.57 \%$ of the respondents inidcated that feedback in performance appraisal influences performance in their organization while $5.43 \%$ disagreed.
From these findings we can deduce that feedback in performance appraisal influences the organizational performance of Murang'a water and Sanitation Company. 


\subsection{Extent of Feedback Influence of Organizational Performance}

The respondents were further asked to indicate the extent to which feedback in performance appraisal influences the organizational performance of Murang'a water and Sanitation Company.

From the findings, $31.52 \%$ of the respondents indicated that feedback in performance appraisal influences the organizational performance of Murang'a water and Sanitation Company, $22.83 \%$ indicated to a very great extent, $21.74 \%$ indicated to a moderate extent, $13.04 \%$ indicated to a low extent and $10.87 \%$ indicated to a no extent at all. From the findings, we can deduce that feedback in performance appraisal influences the organizational performance of Murang'a water and Sanitation Company to a great extent.

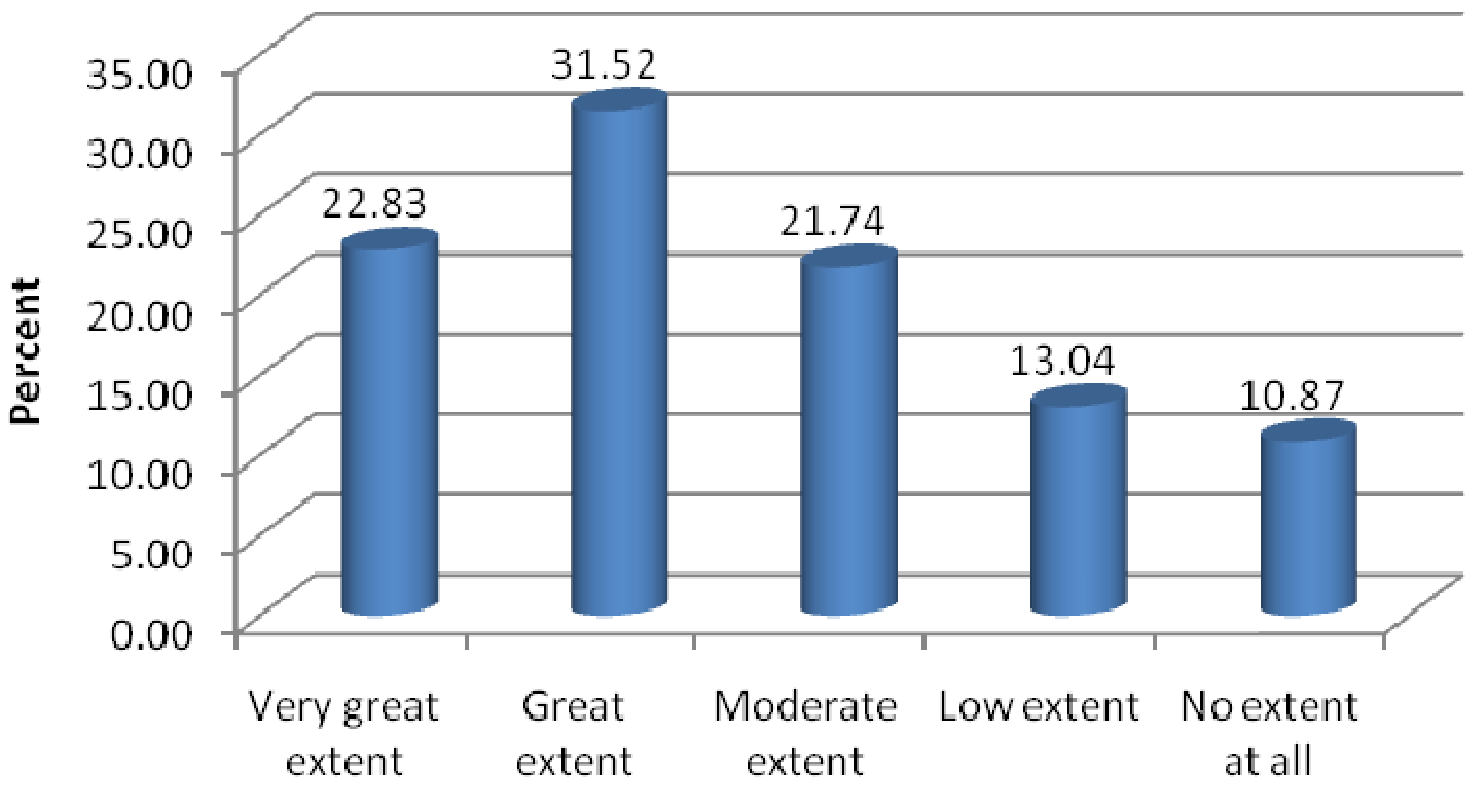

Extent

Source: Researcher, 2013

Figure 5. Extent of Feedback Influence of Organizational Performance.

Table 4. Feedback in Performance Appraisal and Organizational Performance.

\begin{tabular}{lll}
\hline & Mean & $\begin{array}{l}\text { Std } \\
\text { Deviation }\end{array}$ \\
\hline $\begin{array}{l}\text { The organization has developed a strategic plan } \\
\text { which includes program goals as well as goals for }\end{array}$ & 2.398 & 0.972 \\
administrative functions. \\
$\begin{array}{l}\text { The organization has defined performance } \\
\text { indicators for key processes, products and services } \\
\text { and the indicators are monitored and discussed } \\
\text { regularly. }\end{array}$ & 2.144 & 0.723 \\
$\begin{array}{l}\text { A capacity development plan is in place which is } \\
\text { regularly updated. }\end{array}$ & 3.423 & 0.562 \\
$\begin{array}{l}\text { A reward system for good performance is in place } \\
\text { and individual performance is judged based on }\end{array}$ & 2.839 & 0.525 \\
$\begin{array}{l}\text { agreed performance targets. } \\
\text { The organization communicates frequently with } \\
\text { donors, customers and beneficiaries and their } \\
\text { feedback is analyzed and used to improve internal } \\
\text { processes. }\end{array}$ & 3.465 & 0.625 \\
$\begin{array}{l}\text { Management considers good performance a key } \\
\text { issue. }\end{array}$ & & 2.123 \\
$\begin{array}{l}\text { Managers monitor performance in their area of } \\
\text { responsibility. }\end{array}$ & 3.221 & 0.523 \\
$\begin{array}{l}\text { Staff members have the necessary knowledge and } \\
\text { skills to analyze underperformance and find } \\
\text { solutions. }\end{array}$ & 3.434 & 0.726 \\
\hline
\end{tabular}

\begin{tabular}{lcc}
\hline & Mean & $\begin{array}{l}\text { Std } \\
\text { Deviation }\end{array}$ \\
\hline $\begin{array}{l}\text { Staff members are aware of goals and objectives } \\
\text { on organizational level and they know how they } \\
\text { can contribute to these goals and objectives } \\
\begin{array}{l}\text { Members of staff are open to change and } \\
\text { innovation. }\end{array}\end{array}$ & 4.092 & 0.476 \\
$\begin{array}{l}\text { The management has an internal training } \\
\text { programme for all employees }\end{array}$ & 3.423 & 0.562 \\
$\begin{array}{l}\text { The organization can recruit qualified staff } \\
\text { according to its needs. }\end{array}$ & 4.091 & 0.452 \\
$\begin{array}{l}\text { Promotions are based on improved knowledge, } \\
\text { skills and experiences }\end{array}$ & 2.098 & 0.452 \\
$\begin{array}{l}\text { The organization has access to free or affordable } \\
\text { information that may help to improve } \\
\text { performance (e.g. through the internet, public }\end{array}$ & 3.123 & 0.554 \\
$\begin{array}{l}\text { libraries). } \\
\text { Time is lost due to supply problems (e.g. raw } \\
\text { materials). }\end{array}$ & 3.082 & 0.323 \\
$\begin{array}{l}\text { There are delivery delays due to infrastructure } \\
\text { problems. }\end{array}$ & 3.456 & 0.524 \\
\begin{tabular}{l} 
The company website is updated monthly \\
\hline
\end{tabular} & 2.109 & 0.423 \\
\hline
\end{tabular}

Source: Researcher, 2013

According to the findings, the respondents agreed with a mean of 4.234 and a standard deviation of 0.452 that the 
organization can recruit qualified staff according to its needs. In addition, the respondents agreed with a mean of 4.092 and a standard deviation of 0.476 that staff members are aware of goals and objectives on organizational level and they know how they can contribute to these goals and objectives. Further, the respondents agreed with a mean of 3.465 and a standard deviation of 0.625 that the organization communicates frequently with donors, customers and beneficiaries and their feedback is analyzed and used to improve internal processes.

The respondents also agreed with a mean of 3.456 and a standard deviation of 0.524 that there are delivery delays due to infrastructure problems. In addition, the respondents agreed with a mean of 3.434 and a standard deviation of 0.726 that staff members have the necessary knowledge and skills to analyze underperformance and find solutions. Additionally, the respondents agreed with a mean of 3.423 and a standard deviation of 0.562 that a capacity development plan is in place which is regularly updated. Further, the respondents indicated with a mean of 3.423 and a standard deviation of 0.562 that members of staff are open to change and innovation. Further, the respondents agreed with a mean of 3.221 and a standard deviation of 0.526 that managers monitor performance in their area of responsibility. Additionally, the respondents agreed with mean of 3.123 and a standard deviation of 0.554 that the organization has access to free or affordable information that may help to improve performance (e.g. through the internet, public libraries). In addition, the respondents agreed with a mean of 3.082 and a standard deviation of 0.323 that time is lost due to supply problems (e.g. raw materials). The respondents also agreed with a mean of 2.839 and a standard deviation of 0.525 that a reward system for good performance is in place and individual performance is judged based on agreed performance targets.

However, the respondents disagreed with a statement that the organization has developed a strategic plan which includes program goals as well as goals for administrative functions as shown by a mean of 2.398 and a standard deviation of 0.972 . In addition, the respondents disagreed with the statement that the organization has defined performance indicators for key processes, products and services and the indicators are monitored and discussed regularly as a shown by a mean of 2.144 and a standard deviation of 0.723 . Additionally, the respondents disagreed with the statement that management considers good performance a key issue as shown by a mean of 2.123 and a standard deviation of 0.523 . Further, the respondents disagreed with the statement that the company website is updated monthly as shown by a mean of 2.109 and a standard deviation of 0.423 . In addition, the respondents disagreed with the statement that the management has an internal training programme for all employees as shown by a mean of 2.091 and a standard deviation of 0.452 . Lastly, the respondents disagreed with the statement that promotions are based on improved knowledge, skills and experiences as shown by a mean of 2.098 and a standard deviation of 0.342 .

\subsection{Influence of Employees' Knowledge and Skills on Organizational Performance}

The respondents were asked to indicate the extent to which employees' knowledge and skills in performance appraisal influence organizational performance in their organization.

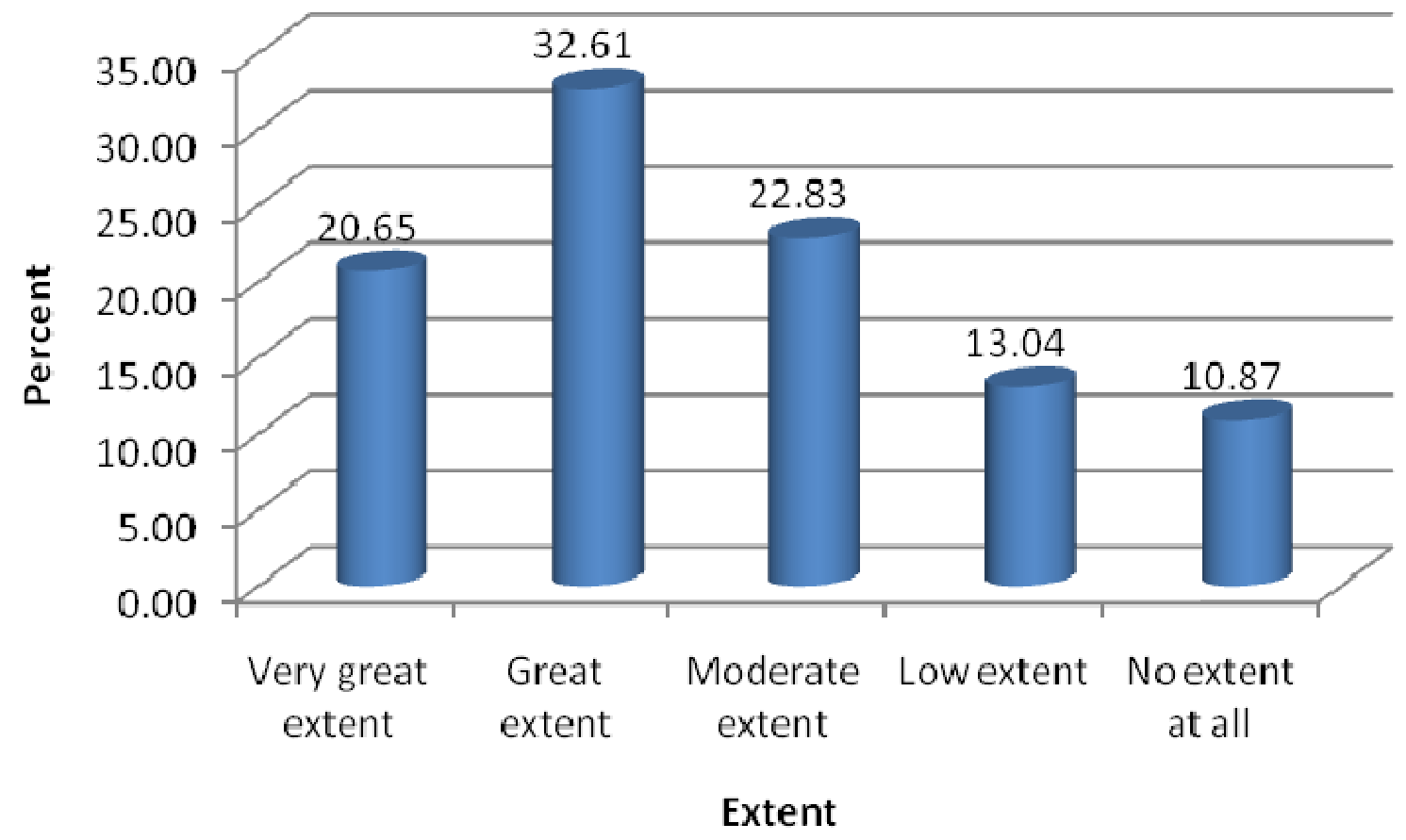

Source: Researcher, 2013

Figure 6. Influence of employees' knowledge and skills on organizational performance. 
Table 5. Effects of Employees' knowledge and skills on organizational performance.

\begin{tabular}{lll}
\hline & Mean & $\begin{array}{l}\text { Std } \\
\text { Deviation }\end{array}$ \\
\hline $\begin{array}{l}\text { Professional knowledge, skills and education may } \\
\text { be useful in an employees' intrinsic motivation so } \\
\text { that the employee is engaged a particular activity. }\end{array}$ & 3.872 & 0.562 \\
$\begin{array}{l}\text { Motivated employees react positively to PA due to } \\
\text { their professional knowledge, individual ability, } \\
\text { skills and good task orientation }\end{array}$ & 4.082 & 0.726 \\
$\begin{array}{l}\text { Motivation, knowledge and independence are useful } \\
\text { components of a worker's day, that may minimize } \\
\text { employees work environment problems }\end{array}$ & 3.982 & 0.627 \\
\hline
\end{tabular}

Source: Researcher, 2013.

According to the findings, $32.61 \%$ of the respondents indicated that employees' knowledge and skills in performance appraisal influence organizational performance in their organization to a great extent, $22.83 \%$ indicated to a moderate extent, $20.65 \%$ indicated to a very great extent, $13.04 \%$ indicated to a low extent and $10.87 \%$ indicate to no extent at all. From these findings we can deduce that employees' knowledge and skills in performance appraisal influence organizational performance in their organization to a great extent.

According to the findings, the respondents indicated with a mean of 4.082 and a standard deviation of 0.726 that motivated employees react positively to PA due to their professional knowledge, individual ability, skills and good task orientation. In addition, the respondents indicated with a mean of 3.982 and a standard deviation of 0.627 that motivation, knowledge and independence are useful components of a worker's day, that may minimize employees work environment problems. Lastly, the respondents indicated with a mean of 3.872 and a standard deviation of 0.562 that professional knowledge, skills and education may be useful in an employees' intrinsic motivation so that the employee is engaged a particular activity.

\subsection{Regression Analysis}

The researcher conducted a multiple linear regression analysis so as to determine the relationship between the organizational performance and the three independent variables namely: of Goal setting in performance appraisal, feedback in performance appraisal, employees' knowledge and skills in performance appraisal.

The regression model was;

$$
\mathrm{Y}=\beta_{0}+\beta_{1} \mathrm{X}_{1}+\beta_{2} \mathrm{X}_{2}+\beta_{3} \mathrm{X}_{3}+\varepsilon
$$

Whereby: $\beta_{0}$ is the regression intercept; $\beta_{1}-\beta_{4}$ are the regression coefficients; $\mathrm{Y}$ is the dependent variable (Organizational Performance); X1 = Goals setting; X2 = Employees knowledge and skills; and X3 = Feedback on appraisal.

The three independent variables that were studied, explain $70.9 \%$ of organizational performance in Murang'a water and Sanitation Company as represented by the $\mathrm{R}^{2}$. This therefore means that other factors not studied in this research contribute $29.1 \%$ of the organizational performance of Murang'a water and Sanitation Company.

Table 6. Model Summary.

\begin{tabular}{lllll}
\hline Model & R & R Square & $\begin{array}{l}\text { Adjusted R } \\
\text { Square }\end{array}$ & $\begin{array}{l}\text { Std. Error of the } \\
\text { Estimate }\end{array}$ \\
\hline 1 & 0.843 & 0.711 & 0.709 & 0.4216 \\
\hline
\end{tabular}

Source: Researcher, 2013

Table 7. ANOVA.

\begin{tabular}{lllllll}
\hline \multicolumn{2}{l}{ Model } & $\begin{array}{l}\text { Sum of } \\
\text { Squares }\end{array}$ & df & $\begin{array}{l}\text { Mean } \\
\text { Square }\end{array}$ & F & Sig. \\
\hline \multirow{4}{*}{$1 \quad$ Regression } & 22.340 & 4 & 5.585 & 2.362 & .022 \\
& Residual & 128.639 & 87 & .688 & & \\
& Total & 150.979 & 91 & & & \\
\hline
\end{tabular}

Source: Researcher, 2013

The significance value is 0.022 which is less that 0.05 thus the model is statistically significance in predicting how Goal setting in performance appraisal, feedback in performance appraisal, employees' knowledge and skills in performance appraisal influence organizational performance in Murang'a water and Sanitation Company. The F critical at 5\% level of significance was 2.362 . Since F calculated is greater than the $\mathrm{F}$ critical (value $=2.290$ ), this shows that the overall model was significant.

Table 8. Coefficient of determination.

\begin{tabular}{|c|c|c|c|c|c|c|}
\hline \multirow{2}{*}{\multicolumn{2}{|c|}{ Model }} & \multicolumn{2}{|c|}{ Un-standardized Coefficients } & \multirow{2}{*}{$\begin{array}{l}\text { Standardized Coefficients } \\
\text { Beta }\end{array}$} & \multirow{2}{*}{$\mathbf{t}$} & \multirow{2}{*}{ Sig. } \\
\hline & & B & Std. Error & & & \\
\hline \multirow[t]{4}{*}{1} & (Constant) & 1.344 & 1.335 & & 1.615 & 0.029 \\
\hline & Goal setting in performance appraisal & 0.421 & 0.128 & 0.265 & 3.982 & 0.021 \\
\hline & Feedback in performance appraisal & 0.425 & 0.241 & 0.076 & 3.643 & 0.023 \\
\hline & $\begin{array}{l}\text { Employees' knowledge and skills in } \\
\text { performance appraisal }\end{array}$ & 0.652 & 0.222 & 0.186 & 3.782 & 0.022 \\
\hline
\end{tabular}

The regression equation will be;

Organizational performance $=1.344+$ Goal setting in performance appraisal $* 0.421+$ Feedback in performance appraisal $* 0.425+$ Employees' knowledge and skills in performance appraisal $* 0.652$

The regression equation above has established that taking all factors into account (Goal setting in performance 
appraisal, feedback in performance appraisal, employees' knowledge and skills in performance appraisal) constant at zero organizational performance in Murang'a water and Sanitation Company will be 1.344. The findings presented also shows that there is a significant positive relationship between Goal setting in performance appraisal and organizational performance in Murang'a water and Sanitation Company as shown by a coefficient of 0.421 . Since the regression coefficient value was more than one we can deduce that there was a relationship between goal setting in performance appraisal and organizational performance. Further, the relationship was found to be significant as the pvalue was less than $0.05(0.021<0.05)$.

In addition, there is a significant positive relationship between feedback in performance appraisal and organizational performance in Murang'a water and Sanitation Company as shown by a coefficient of 0.425 . Since the regression coefficient value was more than one we can deduce that there was a relationship between feedback in performance appraisal and organizational performance This relationship was found to be significant as the $p$-value was less than $0.05(0.023<0.05)$.

Further, the findings show that there is a significant positive relationship between employees' knowledge and skills in performance appraisal and organizational performance in Murang'a water and Sanitation Company as shown by a coefficient of 0.652 . Since the regression coefficient value was more than one, we can deduce that there was a relationship between employees' knowledge and skills in performance appraisal and organizational performance Additionally, the relationship was found to be significant as the $\mathrm{p}$-value was less than $0.05(0.022<0.05)$.

This infers that employees' knowledge and skills in performance appraisal influences the organizational performance in Murang'a water and Sanitation Company most followed by feedback in performance appraisal and goal setting in performance appraisal.

\section{Discussion of the Findings}

\subsection{Goal Setting in Performance Appraisal}

The study sought to determine the effect of goal setting in performance appraisal on organizational performance in Murang'a water and Sanitation Company. It was revealed that goal setting in performance appraisal was influencing organizational performance of Murang'a Water and Sanitation Company Limited to a great extent. In addition, the study revealed that in performance appraisal, the participant may be connected to performance goals, interpersonal goals, strategic goals and internalization goals. Goals also lead to a persistent pursuit of reaching the goal by providing a purpose for that pursuit. In addition, the study found that goal setting is effective as long as employees accept it, and it is a visible process and a key component of PA participation. Further, the study found that performance appraisal probably works best when formal goals, organizational goals, and the ratees' and rater's goals for PA are compatible. The study also found that goal mechanisms affect performance by increasing motivation to reach set goals and energize people to expend more effort based upon the effort that is required to reach a certain goal.

\subsection{Feedback in Performance Appraisal}

The study sought to assess the effects of feedback in performance appraisal on the organizational performance in Murang'a water and Sanitation Company. It was established that feedback in performance appraisal influences the organizational performance of Murang'a water and Sanitation Company to a great extent. According to Heslin, Latham \& VandeWalle (2005), performance appraisal process is incomplete without the feedback given to the employee about his appraisal and his performance. The study also found that Murang'a water and Sanitation Company can recruit qualified staff according to its needs. In addition staff members at Murang'a water and Sanitation Company are aware of goals and objectives on organizational level and they know how they can contribute to these goals and objectives. Further, the study found that the organization communicates frequently with donors, customers and beneficiaries and their feedback is analyzed and used to improve internal processes. Further, the study revealed that the there are delivery delays in the organization due to infrastructure problems. In addition, staff members have the necessary knowledge and skills to analyze underperformance and find solutions.

The study also established that members of staff are open to change and innovation and managers monitor performance in their area of responsibility. Additionally, the organization has access to free or affordable information that may help to improve performance (e.g. through the internet, public libraries). Further, the organization has a reward system for good performance in place and individual performance is judged based on agreed performance targets. However, time is lost due to supply problems (e.g. raw materials).

The study further revealed that the organization had not developed a strategic plan which includes program goals as well as goals for administrative functions. In addition, the organization had not defined performance indicators for key processes, products and services and the indicators are monitored and discussed regularly. Additionally, the management of the organization was not considering good performance a key issue. Further, the company was not updating its website on monthly basis and the management had no internal training programme for all employees. Lastly, promotions in the organization were not based on improved knowledge, skills and experiences.

\subsection{Employees' Knowledge and Skills in Performance Appraisal}

This study sought to establish the effect of employees' knowledge and skills in performance appraisal on the organizational performance in Murang'a water and Sanitation Company. The study revealed that employees' knowledge 
and skills in performance appraisal influence organizational performance in their organization to a great extent. In addition, the study established that motivated employees react positively to PA due to their professional knowledge, individual ability, skills and good task orientation. In addition, the study found that motivation, knowledge and independence are useful components of a worker's day, that may minimize employees work environment problems. These findings agree with Kuvaas (2006) argument that performance appraisal helps employees to improve their performance by giving specific feedback about the need for development, and helps employees to continue to excel by giving positive reinforcement that can motivate them. Further, the study established that professional knowledge, skills and education may be useful in an employees' intrinsic motivation so that the employee is engaged a particular activity.

\section{Conclusion}

The study established that goal setting in performance appraisal influences organizational performance in Murang'a water and Sanitation Company positively. In addition, goals also lead to a persistent pursuit of reaching the goal by providing a purpose for that pursuit. In addition, performance appraisal probably works best when formal goals, organizational goals, and the ratees' and rater's goals for PA are compatible. Further, the study revealed that goal mechanisms affect performance by increasing motivation to reach set goals and energize people to expend more effort based upon the effort that is required to reach a certain goal.

The study further concludes that there is a positive relationship between feedback in performance appraisal and organizational performance in Murang'a water and Sanitation Company. In addition, the study revealed that staff members at Murang'a water and Sanitation Company are aware of goals and objectives on organizational level and they know how they can contribute to these goals and objectives. Further, the organization communicates frequently with donors, customers and beneficiaries and their feedback is analyzed and used to improve internal processes. Additionally, the organization has access to free or affordable information that may help to improve performance (e.g. through the internet, public libraries). However, the organization had not developed a strategic plan which includes program goals as well as goals for administrative functions. In addition, the organization had not defined performance indicators for key processes, products and services and the indicators were not monitored and discussed regularly. Further, the study found that promotions in the organization were not based on improved knowledge, skills and experiences.

The study also concludes that employees' knowledge and skills in performance appraisal influences organizational performance in Murang'a water and Sanitation Company positively. The study also established that motivated employees react positively to PA due to their professional knowledge, individual ability, skills and good task orientation.
In addition, motivation, knowledge and independence are useful components of a worker's day, that may minimize employees work environment problems. Further, professional knowledge, skills and education may be useful in an employees' intrinsic motivation so that the employee is engaged a particular activity.

\section{Recommendation for Further Studies}

This study focused on performance appraisal and organizational performance in water and sanitation companies in Murang'a County. However, the study was limited to Murang'a water and Sanitation Company and hence its findings cannot be generalized to other water and sanitation companies in Kenya. This study therefore recommends further studies in the area of the role of performance appraisal in organizational performance in water and sanitation companies in Kenya. In addition other organizations would use this study as a benchmark to carry out performance appraisal studies aimed at improving organizational performance. The government of Kenya in its effort to improve public service delivery would carry out standardized baseline surveys to document the current status of Water and Sanitation companies in Kenya in a bid to realize high standard services.

\section{References}

[1] Allred S. \& BRoss-Davis, A. (2010). The Drop-off and Pickup Method: An Approach to Reduce Nonresponse Bias in Natural Resource Surveys, Springer: Small-scale Forestry.

[2] Cameron, J. \& Pierce, W. D. (2004) Reinforcement, Reward and Intrinsic Motivation: A meta-Analysis. Review of Educational Research, 64(3):363-423.

[3] Cardy, R. L. \& Dobbins, G. H. (2008). Performance Appraisal: Alternative Perspectives. Cincinnati, OH: South-Western Publishing.

[4] Caruth, D. L \& Humphreys J. H. (2008). Performance appraisal: Essential characteristics for strategic control. Measuring Business Excellence, 12 (3), 24-32.

[5] Deci EL, Connell JP \& Ryan RM (2008) Self-determination in Human Behavior. Journal of Applied Psychology, 74, 580-590.

[6] Divandari, A. (2008), Providing Comprehensive System Design And Performance Appraisal Of Staff Banking System (Bank Samples Nation), Journal of Industrial Management Science Department, Azad University of Sanandaj, 3(5), 103115 .

[7] Dunning, D., Durham, T., \& McDonough, D. (2012). Performance feedback as viewed by Dental Assistants: Part II. Dental Assistant (Chicago, Ill.: 1994), 81(6), 6-8.

[8] Gbadamosi, G., \& Ross, C. (2012). Perceived Stress and Performance Appraisal Discomfort: the Moderating Effects of Core Self-Appraisals and Gender. Public Personnel Management, 41(4), 637-659. 
[9] Gupta, V., \& Kumar, S. (2013). Impact of performance appraisal justice on employee engagement: a study of Indian professionals. Employee Relations, 35(1), 61-78.

[10] Heslin, P. A., Latham. G. P. \& VandeWalle, D. (2005). The effect of implicit person theory on performance appraisals. Journal of Applied Psychology. 90(5), 842-56.

[11] Kipyegon, J. (2012). The effectiveness of staff performance appraisal as value addition strategy in organizations within electricity sub-sector in Kenya. Retrieved on $6^{\text {th }}$ June 2013 from http://ir-library.ku.ac.ke/etd/handle/123456789/1730.

[12] Kothari, C. R. (2004). Research methodology: Methods and techniques. New Delhi: New Age International (P) Limited Publishers.

[13] Kuvaas, B. (2006). Different Relationships between Perceptions of Developmental Performance Appraisal and Work Performance. Personnel Review, 36(3), 378-398.

[14] Latham, G. P. (2004). The motivation benefits of goal setting. Academy of Management Executive, 18(4), 126-129.

[15] Lee, R. (2004). Employee Performance Appraisal and the 95/5 Rule Community College, Journal of Research and Practise,28(5), 407-414.

[16] Locke, E. A., \& Latham, G. P. (2006). New directions in goalsetting theory. Current Directions in Psychological Science, 15(5), 265-268.

[17] Payne, J. H. (2005). Reconceptualizing social skills in organizations: exploring the relationship between communication competence, job performance, and supervisory roles, Journal of Leadership \& Organizational Studies 11(2), 63-77.
[18] Pichler, S. (2012). The social context of performance appraisal and appraisal reactions: A meta-analysis. Human Resource Management, 51(5), 709-732.

[19] Prowse, P. \& Julie, P. (2009). The dilemma of performance appraisal., Measuring Business Excellence, 13(4), 69- 77.

[20] Rotich, R. K. (2012). The impact of performance appraisal on staff development: a case of selected multinational companies in Kericho, Kenya. Retrieved on $6^{\text {th }}$ June 2013 from http://etdlibrary.ku.ac.ke:8080/etd/handle/123456789/1234.

[21] Salleh, M., Amin, A., Muda, S., \& Abdul Halim, M. (2013). Fairness of Performance Appraisal and Organizational Commitment. Asian Social Science, 9(2), 121-128.

[22] Selvarajan, T. T., \& Cloninger, P. A. (2012). Can performance appraisals motivate employees to improve performance? A Mexican study. International Journal Of Human Resource Management, 23(15), 3063-3084.

[23] Thurston, P. W \& McNall, L (2010). Justice perceptions of performance appraisal practices. Journal of Managerial Psychology, 25 (3), 201-228.

[24] Tuytens, M., \& Devos, G. (2012). Importance of system and leadership in performance appraisal. Personnel Review, 41(6), 756-776.

[25] Walsh, K. \& Fisher, D. (2005). Action inquiry and performance appraisals: Tools for organizational learning and development. Journal of the Learning Organization, 12 (1), 26-41.

[26] Whiting, H., Theresa J. B. \& Sulsky, M. (2008). The performance appraisal congruency scale: an assessment of person-environment fit, International Journal of Productivity and Performance Management, 57(3), 223 - 236. 